\title{
Security Interests in Government Contracts: Wherein the Tortoise Wins the Res
}

When the Department of Defense advances money to a contractor in the form of progress payments, ${ }^{1}$ it secures the loan by taking title to most of the contractor's personalty associated with the contract. If the contractor thereafter becomes insolvent, the Defense Department may reclaim this property, setting off the contractor's debts against its obligation to pay for the property. To the extent that the value of the property covers the contractor's indebtedness, this setoff enables the government to obtain payment in full before all other claims are satisfied.

A secured party must normally file his security interest so that prospective creditors will be notified that part of the debtor's property is subject to a prior claim. Otherwise, state law ${ }^{2}$ and the federal Bankruptcy $\mathrm{Act}^{3}$ will usually invalidate his interest, thereby reducing him to the status of an unsecured creditor. When progress payments are involved, however, the federal courts have allowed the Defense Department to enforce its security interests ${ }^{4}$ without filing or other notifica-

1 "Progress payments" is the term used in the Armed Services Procurement Regulations (hereinafter cited as ASPR), 32 C.F.R., pts. 1-39 (1966), to describe periodic advancements of money to the contractor after the latter has commenced contract performance and incurred costs. Essentially loans, the payments are subject to repayment in accordance with terms contained in the contract. 32 C.F.R. \$ 163.79-1 (1966). To be distinguished from progress payments are "advance payments," monies advanced before the contractor incurs any costs, 32 C.F.R. \& 163.64-2 (1966), and "partial payments," which represent final payments for partial deliveries accepted by the government. 32 C.F.R. $\$ 163.78-1$ (1966).

When granting progress payments, the Department of Defense considers both the size of the contract and the financial ability of the contractor. Contracts in excess of one million dollars that require substantial expenditures for at least six months before any products are completed customarily receive progress payments if the contractor is financially sound. 32 C.F.R. § 163.72 (1966).

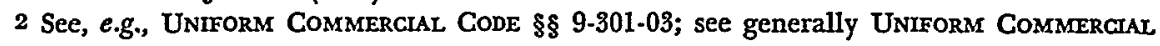
CODE $\S 9$, pt. 3 .

By requiring filing of the security interest in a public place, such as the Office of the Secretary of State, the statutes give creditors an opportunity to discover the presence of the security interest if they so desire. Such opportunity is deemed to be equivalent to public notification. See generally 1 Coogan, Hogan \& Vagts, Secured Transactions Under the UNIFORM COMMERcial CODE 461 (1963).

330 Stat. 565 (1898), as amended, 52 Stat. 879 (1938), 11 U.S.C. \& 110(e)(1) (1964).

4 The Uniform Commercial Code's definition of a security interest as "an interest in personal property or fixtures which secures payment or performance of an obligation ....," UNIFORM COMMERCIAI CODE § 1-201(37), encompasses the government's title. The latter 
tion to third parties, ${ }^{5}$ even though prospective creditors have no reliable way to determine whether the contractor's property is encumbered by that agency.

In resolving contests between the Department and private parties for the senior claim to the collateral covered by the progress payments clause, the federal courts have applied federal common law, referred to the Constitution, and searched for the location of "title." Their analysis has disregarded the fact that the title is essentially a security interest. After describing the contractual provisions and judicial doctrines that permit the Department to obtain priority over many competing parties, this comment will suggest that the government should file its security interest ${ }^{6}$ and will propose several methods by which such a requirement might be effected. The "first in time, first in right" rule that the courts have adopted to resolve priority struggles will also be compared with the Uniform Commercial Code's priority system. Finally, it will be suggested that, drawing from the Code, courts might modify that statute's rules and determine priority questions on the basis of four policy considerations that seem to make more meaningful distinctions among security interests than do the courts' federal common law and "title" analyses.

Under the standard Armed Services Procurement Regulations (ASPR), ${ }^{7}$ the progress payments clause ${ }^{8}$ provides the contractor with

both secures payment of the contractor's liabilities and facilitates rapid contract performance. See generally Gilmore, Article 9: What It Does Not Do for the Future, 26 LA. L. Rev. 300, 302-04 (1966).

5 In United States v. Ansonia Brass \& Copper Co., 218 U.S. 452 (1910), the Court established the special treatment accorded the Department by holding that if a contract passed title to specific property to the government, private liens in that property could not be enforced. Since World War II, the following federal cases expanded and modified the Ansonia principle: United States v. Armstrong, 364 U.S. 40 (1959); Shepard Engineering Co. v. United States, 287 F.2d 737 (8th Cir. 196I), aff'd on rehearing, 289 F.2d 681 (8th Cir. 1961); In re American Boiler Works, Inc., 220 F.2d 319 (3d Cir. 1955); In re Greenstreet, 209 F.2d 660 (7th Cir. 1954); In re Read-York, Inc., 152 F.2d 313 (7th Cir. 1945); United States v. Ameco Electronic Corp., 224 F. Supp. 783 (E.D.N.Y. 1963); Thomson Machine Works Co. v. Lake Tahoe Marine Supply Co., 135 F. Supp. 913 (N.D. Cal. 1955).

6 Although this comment is specifically aimed at the security interest created by the progress payments clause, the arguments in favor of creditor notification apply with equal force to all secret security interests that are enforceable. In particular, paramount liens that secure repayment of Defense Department "advance payments" should probably also be filed even though the encumbered property is segregated and identified as subject to a paramount lien. See 32 C.F.R. \$ 163.64-2 (1966).

7 These regulations specify the clauses that government contracting officers may insert in contracts. The statutory authority for the progress payments clause is the Armed Services Procurement Act of 1947, 62 Stat. 21, 10 U.S.C. $\S 2307$ (1964), that authorizes 
financing for the contract. 9 The government agrees to reimburse him periodically for up to seventy per cent of all costs that have been incurred in connection with the contract. ${ }^{10}$ In return, the contractor agrees that title to all his materials, supplies, and nondurable tools associated with the contract shall vest in the Defense Department when the contract is signed.11 Title to all such items later acquired, including

progress payments "if secured by adequate security." Although the act states that the security may be in the form of a lien on the property that is paramount to all other liens, neither it nor the legislative history further specify the definition of "adequate security." The legislative history of the act does not suggest hostility to mandatory filing of the Department's security interest. See 93 CoNG. REc. 2318-28 (1946).

Substantially the same title passing provisions are recommended by the Administrator of General Services for all federal government procurement contracts. See 41 C.F.R. $\$ \$ 1-30.503,1-81701,1-81707$ (1966). The various agencies are free, within limitations, to modify or supplement these clauses as they see fit. See, e.g., 41 C.F.R. pts. 5-7 (1966).

Many of the ASPR clauses are mandatory in certain types of contracts; for example, if progress payments are provided, one of two standard clauses must be inserted. If the contracting officer neglected to insert a required clause in the completed contract, however, it would seem that the parties would be bound only by the written instrument. To the contrary, the Court of Claims recently held that an omitted termination for the convenience of the government clause that was required by the ASPR would be read into the contract after the government's default. G. L. Christian \&: Associates v. United States, 312 F.2d 418 (Ct. Cl. 1963); Comment, Defense Contractor's Peril: The Written Agreement May Not Contain All the Terms, 37 So. CAL. L. REv. 452 (1964). The holding seems to imply that a contract providing for progress payments would have the title passing provision read into it if it were omitted. Such a development might jeopardize secured creditors' interests in the contractor's property even more than the existing arrangement.

832 C.F.R. \& 163.79-1 (1966). The progress payments, default, and termination for convenience clauses that are discussed in this comment are the ones required for fixedprice supply contracts. However, other Defense contracts, such as those for research and development and those that pay the contractor according to a cost-reimbursement principle, contain similar clauses. See 32 C.F.R. pt. 7 (1966).

9 Contractors prefer progress payment financing to borrowing from commercial sources since the government's advances are interest free. The Department of Defense will normally also favor such financing since, by reducing the contractor's capital cost, the advances help reduce the contract price. See generally Whelan, Government Supply Contracts: Progress Payments Based on Costs: The New Defense Regulations, 26 FORDHAM L. Rev. 224 (1957); McClelland, The Illegality of Progress Payments as Means of Financing Government Contractors, 33 Notre DAME LAw. 380 (1958).

1032 C.F.R. § 163.79-1 (1966). Comparison with other provisions of the clause emphasize that the government holds this title only as a security device. Bearing the risk of theft, loss, or fire, id. \& 163.79-1(e), the contractor may dispose of scrap and, with the contracting officer's permission, may sell the property. $I d$. \& 163.79-I(d). Further, the Department may still reject the product at the time of final inspection. Id. \& 163.79-1(i). Moreover, the elaborate regulations that contractors possessing government furnished property must heed do not apply to this property. Id. \$ 163.79-1(d).

Alternatively, the government sometimes provides up to $85 \%$ of direct labor and materials costs, excluding reimbursement for such items as factory overhead. 32 C.F.R. § 163.79-2 (1966).

11 Specifically, the contractor agrees that: "Immediately, upon the date of this contract, title to all parts; materials; inventories; work in progress; special tooling . . . ; nondurable (i.e., noncapital) tools, jigs, dies . . . theretofore acquired or produced by the Contractor 
both partially and fully completed products, shall vest in the government upon acquisition by the contractor. ${ }^{12}$

If the contractor becomes insolvent and defaults, ${ }^{13}$ the Department of Defense may file a reclamation petition ${ }^{14}$ and reclaim from the trustee in bankruptcy all the property to which title has passed under the contract. ${ }^{15}$ Although the contract provides that the contractor will receive reasonable value for the property so reclaimed,,$^{16}$ the government's payment is considerably reduced because it first deducts the contractor's liabilities; specifically, it subtracts his obligations to repay all progress payments ${ }^{17}$ and to pay for all costs in excess of the contract price that are necessary in order to have someone else complete the contract. ${ }^{18}$ Thus, by holding title to the contractor's property, the

and allocated ... to this contract . . . shall forthwith vest in the Government; and title to all like property thereafter acquired or produced ... shall forthwith vest in the Government upon said acquisition ...." 32 C.F.R. § 163.79-1(d) (1966).

12 Although title vests in the government, the progress payments clause also provides that if the contractor defaults, he may be required to execute an instrument of title transfer. The purpose behind requiring such an instrument is unclear. Compare 32 C.F.R. § 163.79-1(d) (1966) with 32 G.F.R. § 8.707 (1966) and 32 C.F.R. § 163.94-4 (1966).

On the other hand, if the contractor fully performs his obligations, "any excess property remaining is to be regarded as having not been allocated or properly chargeable to the contract ... and thus outside the scope of the Progress Payment clause which would have vested title in the Government." 32 C.F.R. $\$ 163.94-5(\mathrm{~b})$ (1966).

13 In those contracts that give the government the power to terminate at any time, the Department of Defense might attempt to obtain the property prior to insolvency. If soon thereafter the contractor became bankrupt, for example, if the contract termination caused or anticipated his financial problems, a bankruptcy trustee might attempt to invalidate the government's priority under $\S 60$ of the Bankruptcy Act, 30 Stat. 562 (1898), as amended, 52 Stat. 869 (1938), 1I U.S.C. $\$ 96$ (1964). Section 60 normally invalidates the preference that an unperfected secured creditor receives by being paid in full rather than sharing in the bankruptcy dividends. While there are no cases in which this happened, one would assume that, to be consistent, the courts would either exempt the Department of Defense from this section of the Bankruptcy Act or would hold that the government's interest is perfected and thus not vulnerable to $\S 60$. See also note 74 infra.

14 After stating that he holds title to the property, the petitioner asks the trustee to deliver possession. See generally Central States Corp. v. Luther, 215 F.2d 38 (10th Cir. 1954), cert. denied, 348 U.S. 951 (1955); In re Morley, 29 F. Supp. 979 (D.C. Pa. 1939), and cases cited therein; 4 CoLrIer, BANKRuPTCY $\$ 70.39$ (14th ed. 1964).

15 Since the trustee normally holds title to all of the bankrupt's property, he may usually resist the petition successfully if the secured party's interest is unperfected. See 30 Stat. 562 (1898), as amended, 52 Stat. 869 (1938), 11 U.S.C. $\S 96$ (1964). When the Department of Defense petitions, however, such trustee resistance has been futile, see, e.g., In re Read-York, Inc., 152 F.2d 313 (7th Cir. 1945), thus implying that the Defense Department's title is considered perfected.

16 Compare 32 C.F.R. § 8.707(d) (1966) with 32 C.F.R. § 7.103-12 (1966).

1732 C.F.R. $\$ 163.79-1$ (b) (1966).

1832 C.F.R. \$ 8.707(b) (1966). For example, in Armstrong v. United States, 364 U.S. 40 (1959), the Department of Defense attempted to set off a portion of its $\$ 146,000$ claim for such excess costs even though repayment of the progress payments was secure. See the case on remand, 287 F.2d 577 (Ct. Cl. 1961). 
government secures full payment of its claims to the extent that the value of the property covers them.19

When the contractor is insolvent, this method of assuring payment of the Defense Department's claims may have a substantial adverse impact on creditors whose claims are thereby subordinated to those of the government. ${ }^{20}$ The normal order in which a bankrupt's assets are distributed to creditors was established by Congress in the Bankruptcy Act. Secured creditors' claims are first paid in full to the extent of the collateral. ${ }^{21}$ Then the expenses of administration, materialmen's claims, debts due the government, and unsecured obligations are satisfied in that order, ${ }^{22}$ all claims in a given category being paid in full before any claims in the succeeding group receive anything.

Avoiding the ordinary statutory priorities, the contract provisions that vest title in the government convert the relevant property from general assets of the contractor into collateral securing the contractor's debts owed to the Defense Department. Thus, the agency's claims are advanced from the fourth classification (debts due the government) to the first (secured obligations). If the government's secured claims exhaust the debtor's assets, neither materialmen's claims ${ }^{23}$ nor the expenses of administration will be satisfied. More significantly, if successful in claiming specific property as collateral for its claims, the Defense Department will displace any secured creditors who have perfected security interests in that same property ${ }^{24}$ if their interests were acquired after the signing of the contract. ${ }^{25}$ These creditors will have only a security interest in the value of the property in excess of the

If the contractor's default results from forces beyond his control, however, he is not liable for these excess costs. 32 C.F.R. $\$ 8.707$ (d) (1966).

10 If the value of the reclaimed property exceeds the contractor's liabilities, the Department of Defense will, of course, refund the excess. See 32 C.F.R. $\$ 8.707$ (d) (1966).

20 Neither Defense Department publications nor inquiries from this author to that agency have disclosed the number, size, or other characteristics of defense contractors that become bankrupt. Perhaps the Department does not have such information readily available.

2130 Stat. 560 (1898), 11 U.S.C. § 93(h) (1964).

2230 Stat. 568 (1898), 11 U.S.C. \$ 104(a) (1964).

23 E.g., Thomson Machine Works Co. v. Lake Tahoe Marine Supply Co., 135 F. Supp. 913 (N.D. Cal. 1955).

24 This possibility would seem to be the greatest threat to a contractor's creditors since many contractors may require private financing in addition to the progress payments. The cases, however, are predominately brought by materialmen with statutory mechanics liens. E.g., United States v. Ameco Electronic Corp., 224 F. Supp. 783 (E.D.N.Y. 1963). The lack of suits by secured creditors may result from settlements with the government or a sense of hopelessness engendered by the existing case law.

25 Armstrong v. United States, 364 U.S. 40 (1959), established that secured parties' interests are valid if acquired before the contract is signed, i.e., before the government obtained title to the property. 
Department's claims, since private liens cannot attach to property to which the federal government holds title. ${ }^{26}$ In most cases, the private party would then have to present an unsecured claim in bankruptcy, the government's claims having exhausted the collateral. Since unsecured creditors in bankruptcy recover on an average only about eight cents on the dollar as compared to sixty-six cents on the dollar for secured parties, ${ }^{27}$ a lender would normally suffer a substantially larger financial loss due to the government's unfiled title.

Since United States v. Ansonia Brass and Copper Co., ${ }^{28}$ the federal courts have consistently held that the government can reclaim property under a contract that passes title without filing its interest. ${ }^{29}$ Despite the Bankruptcy Act's provision ${ }^{30}$ specifying that state law shall govern the validity of security interests, which in effect requires that security interests similar to the Department's must be filed to be enforceable, the Third and Seventh Circuits" maintain that "specialized federal common law"32 supplants the Act and immunizes the Department

26 United States v. Munsey Trust Co., 332 U.S. 234 (1946); Equitable Surety Co. v. United States ex rel. McMillan \&: Son, 234 U.S. 448 (1913). State liens are also unenforceable in this situation. United States v. Alabama, 313 U.S. 274 (1941).

27 The $8 \%$ and $66 \%$ figures refer only to the $13 \%$ of all bankruptcy cases in which creditors recover anything. In the remaining $87 \%$ of the cases, there are either no assets or only nominal assets. Countryman, The Bankruptcy Boom, 77 HARv. L. REv. 1452, 1454 (1964).

28218 U.S. 452 (1910). In Ansonia, materialmen's liens were rendered unenforceable because the prime contract, as the Court read it, had passed to the government title to partially completed ship hulls, presumably the only property available to satisfy the liens. $I d$. at 461, 466. Although filing was not discussed in the case, Ansonia has been regularly cited for the proposition that the Department of Defense need not file its security interest. See, e.g., In re American Boiler Works, Inc., 220 F.2d 319, 320 (3d Cir. 1955).

Analyzing the parties' contractual intent, the Court concluded that title passed to the government as a result of their agreement that: "The parts [of the ship] paid for under the system of partial payments [progress payments] above specified shall become thereby the sole property of the United States ... ." 218 U.S. at 466. In two other contracts the bankrupt had with the government, however, the progress payments were secured by a lien, and Ansonia's statutory lien was held to be superior to the government's claim. Thus, the Court appeared to be saying that by changing the words in the contract from "lien" to "title," the security interests of private creditors could be rendered unenforceable in bankruptcy. See id. at 474 .

29 E.g., In re American Boiler Works, Inc., 220 F.2d 319 (3d Cir. 1955); In re ReadYork, Inc., 152 F.2d 313 (7th Cir. 1945); cf. In re Greenstreet, Inc., 209 F.2d 660 (7th Gir. 1954).

Besides reclaiming property from a bankruptcy trustee, the government may, without incurring liability, replevy vested property that was sold by a contractor to a good faith purchaser. Shepard Engineering Co. v. United States, 287 F.2d 737 (8th Cir. 1961).

3030 Stat. 565 (1898), as amended, 52 Stat. 879 (1938), II U.S.C. § $110(\mathrm{e})(1)$ (1964).

31 In re American Boiler Works, Inc., 220 F.2d 319 (3d Cir. 1955); In re Read-York, Inc., 152 F.2d 313 (7th Cir. 1945).

32 This phrase is from an article by Judge Henry J. Friendly in which he states: "[B]y banishing the spurious uniformity of Swift $v$. Tyson ... Erie led to the emergence of a 
from filing requirements. ${ }^{33}$ Presumably, the purpose behind a federal common law is to provide uniformity to divergent law when such is necessary for the national interest. ${ }^{34}$ It is doubtful, however, that the uniformity that results from exempting the Department of Defense from varying state filing requirements is necessary for the national interest, or, indeed, is worth the possibility of leading prospective secured creditors to believe that the collateral is unencumbered.

The Department of Defense's ability to reclaim was modified by the Supreme Court's decision in Armstrong $v$. United States, ${ }^{35}$ which held that when the government acquires its title after another lienholder, the government's action in reclaiming the property amounts to a taking in violation of the fifth amendment; therefore, prior lienholders must be compensated for the value of the interests rendered unenforceable by the government's action. ${ }^{36}$ Before this decision, the government

federal decisional law in areas of national concern that is truly uniform . . . [a] specialized federal common law." Friendly, In Praise of Erie-And of the New Federal Common Law, 39 N.Y.U.L. REv. 383, 405 (1964).

33 The authority relied upon by the circuit courts in their application of federal common law was very weak. It was a quotation from United States v. Allegheny County, 322 U.S. 174 (1944), to the effect that federal statutes may declare government liens that need not be filed. In these cases, however, federal contracts rather than federal statutes were involved. Furthermore, Allegheny's references to federal statutory liens were dicta; the Supreme Court was concerned with the state of Pennsylvania's attempt to impose a tax on machinery to which the government held title.

34 See Clearfield Trust Co. v. United States, 318 U.S. 363 (1943).

35364 U.S. 40 (1959). The prime contractor, Rice Shipbuilding Corp., agreed to construct Navy personnel boats. Having furnished materials for use in the construction, Armstrong and others obtained mechanics liens according to the laws of Maine, which could be enforced by attachment. When Rice became insolvent, it conveyed title to the hulls and other manufacturing materials to the government in accordance with a default clause in the contract that allowed the contracting officer to require such a conveyance. Armstrong's liens were consequently useless since-the government then owning the property - they could no longer be enforced by attachment.

36 Somewhat unclear, the Court's reasoning seemed to proceed as follows. Under earlier fifth amendment decisions, the right to resort to specific property for the satisfaction of one's claim is compensable property. Armstrong's lien was such a right. When it required the contractor to transfer title, the government totally destroyed the value of the lien since it could no longer be enforced. Therefore, the government's action was a fifth amendment taking of property that required just compensation. See 364 U.S. at 48.

Since Armstrong had not been notified by filing of the Department of Defense's security interest, the Court's holding appropriately required the government to reimburse the lienholders. On the other hand, the logic supporting this result was weak in two respects. The opinion failed to mention that the government could have protected its interests by filing or other notification of prospective creditors. Further, it implied that if private liens had attached after the Department of Defense obtained title, the latter would not have had to compensate the lienholders.

Mr. Justic Black also suggested that Ansonia was incorrectly decided, noting that the "Fifth Amendment question was not raised or passed upon" in the earlier case. 363 U.S. at 47 . 
had used two standard ASPR clauses-the default clause ${ }^{37}$ and the termination for the convenience of the government clause $^{38}$-to create security interests by requiring the contractor to transfer title to all associated personalty to the government at the time of default or termination. ${ }^{30}$ Since Armstrong, a security interest created by either of these two clauses will rarely, if ever, financially injure secured creditors or materialmen since the latter parties normally perfect their interests prior to default or termination of the contract. The progress payments clause, however, by vesting title in the government immediately upon the signing of the contract, continues to create unfiled security interests superior to the interests of subsequent secured creditors and materialmen. ${ }^{40}$

If the private party knew of the government's title, or should have known of it, the agency's failure to file the progress payments clause will not significantly harm him since the purpose of filing is to notify other creditors of a secured party's claim. In particular, large institutional lenders probably realize that the federal government may not file all of its security arrangements and are thus wary if they discover that the prospective debtor has a defense contract. On the other hand, a lender may not know that a subcontractor ${ }^{41}$ is dealing with the federal government, especially when there are several tiers of subcontracting. Furthermore, small businesses that qualify for the advances ${ }^{42}$ may

37 32 G.F.R. § 8.707 (1966).

3832 C.F.R. $\$ 8.701$ (1966).

39 See note 30 supra. Armstrong illustrated how these clauses operated. Thus, if a bank or materialman had a security interest in the contractor's machinery, the government could terminate the contract, require the contractor to transfer title, and render the private party's interest unenforceable. See, e.g., Thomson Machine Works Co. v. Lake Tahoe Marine Supply Co., 135 F. Supp. 913 (N.D. Cal. 1955).

40 E.g., United States v. Ameco Electronic Corp., 224 F. Supp. 783 (E.D.N.Y. 1963).

41 Although the text refers primarily to contracts with prime contractors and the possible injury to their creditors, the same situation is presented when subcontractors receive progress payments from the Department of Defense through the prime contractor. If the subcontract contains a clause equally as favorable to the government as the standard progress payments clause, thus vesting title to the subcontractor's personalty directly in the government, the latter will advance the subcontractor up to $70 \%$ of his total costs. 32 C.F.R. §§ $163.79(j), 163.82-2$ (1966). As with prime contracts, the Department's title is not filed. The parallel between prime contractors and subcontractors was recently increased when the Ninth Circuit expanded the scope of federal common law to include government subcontracts. American Pipe \& Steel Corp. v. Firestone Tire \& Rubber Co., 292 F.2d 640 (9th Cir. 1961).

42 Although large contractors normally do not receive progress payments on contracts of less than $\$ 1,000,000$, the size of the contract is not a factor in awarding progress payments to small business concerns. Reliable, competent small businesses are customarily given progress payments if substantial expenditures must be made for at least six months before any products are completed. Further, small businesses may routinely receive $75 \%$ reimbursement, rather than the usual 70\% progress payments. 32 C.F.R. $\$ 163.72$ (1966). 
borrow from an equally small, local bank that could not be expected to be on notice of the possibility of the government's security interest solely because the firm had a defense contract. ${ }^{43}$ In either of these cases, if a lender advanced money after the government contract was signed and the debtor later became insolvent, the private party's claim would be subordinated to that of the Defense Department.

While freedom from filing ${ }^{44}$ may be advantageous in that it relieves the government of an onerous task, such relief should be balanced against the resulting disadvantages to private parties that result from nonfiling. A filing system simultaneously furthers the goals of debtors, secured parties, and third parties by providing that a perfected interest is generally superior to unperfected and subsequently perfected ones. ${ }^{45}$ Debtors' attempts to borrow money are facilitated since third parties may, by searching the files, discover many liens that might encumber the collateral; by filing, secured parties are protected from most unfiled interests. When a defense contract is involved, however, those who ex-

43 For an example of a relatively small contractor, see Shepard Engineering Co. v. United States, 287 F.2d 737 (8th Cir. 1961), where the subcontractor, a good faith purchaser, bought title vested property from the prime contractor. When the latter became insolvent, the government reclaimed the property, leaving the subcontractor with only an unsecured claim against the bankrupt seller. It seems likely that the contractor either did not realize the significance of the progress payments clause or forgot about it.

44 See also UNIFORM COMMERCIAL CODE § 9-802. If the government were treated as a private party, its title would probably be invalidated in bankruptcy since the security interest had not been perfected. 30 Stat. 565 (1898), as amended, 52 Stat. 879 (1938), 11 U.S.C. § 110 (e)(1) (1964); Uniform Commerclal Code $\$ \S 9-301-03$. See also Uniform Commercial Code $\$ 2-401(1)$, dealing with the seller's retention of titie to goods in the buyer's possession. See generally Speidel, Advance Payments in Contracts for Sale of Manufactured Goods: A Look at the Uniform Commercial Code, 52 CALrF. L. Rev. 281 (1964); Note, Bankruptcy and Article Two of the Uniform Commercial Code: The Right to Recover the Goods Upon Insolvency, 79 HARv. L. REv. 598 (1966).

Prior to the Code, a private buyer, who financed his seller in the manner that the government finances its contractors, was subject to the doctrine of reputed ownership. Starting with the Statute of 13 Eliz. 1 c. 5 (1570), and Twynes Case, 3 Coke 80b, 76 Eng. Rep. 809 (Star Chamber 1601), the courts distrusted situations in which a buyer allowed a seller to retain possession of property to which the buyer had title. Although many states adopted a "fraud-in-law" doctrine, conclusively holding that transaction void as against creditors, e.g., Sturtevant \& Keep v. Ballard, 9 Johnson 337 (Supp. Ct. Jud. N.Y. 1811), the majority of the states had a rebuttable presumption of fraud. 2 Wiruston, SAles §§ 354-404 (rev. ed. 1948); see, e.g., Southern Cal. Collection Co. v. Napkie, 106 Cal. App. 2d 565, 235 P.2d 434 (1951); Davis v. Turner, 4 Grattan 422 (Ct. App. Va. 1848). Although the Uniform Commercial Code continues the doctrine of reputed ownership in \$ 2-402(2) ("A creditor may treat a sale or an identification of goods to a contract for sale as void if as against him a retention of possession by the seller is fraudulent under any rule of law of the state ...."), it also allows a buyer to perfect a security interest in the seller's property to secure the former's advances. UNIFORM COMMERcial CoDE $\S$ 1-201(37), 9-302.

45 This generalization is quite broad. See, e.g., UNIFORM COMMERCLAL CODE $\$ \S 9-301-05$, 312. 
tend credit to the contractor may advance money to the contractor on the basis of an erroneous belief that the latter's collateral is unencumbered. Moreover, private parties may not be able to protect their advances by filing their interests because private liens cannot attach to government property. ${ }^{46}$ As a consequence, the contractor may find it more difficult to obtain credit, ${ }^{47}$ especially in light of the unfortunate results caused by the existence of a prior government security interest - subordination of the private security interest to the Department's claim.

The disadvantage to the Department of Defense of filing its title seems to be the effort that would be necessary to locate the public records and complete the requisite forms. But this task has been considerably simplified by the adoption of the Uniform Commercial Code in all but three of the states. ${ }^{48}$ Even before the Code was so widely accepted, the Farmers Home Administration and the Small Business Administration, without apparent difficulty, filed their security interests $^{49}$ in compliance with the relevant state statutes.50 Failure by the Small Business Administration properly to do so has resulted in the security device being declared invalid in bankruptcy, ${ }^{51}$ thus subordinating that agency's claim to its usual priority classification as a debt due the government.

The additional administrative expense that filing would create for the Department would seem to be insubstantial when compared to the benefit that private creditors would thereby receive. The virtually unanimous judgment of the courts and legislatures ${ }^{52}$ in requiring pri-

46 See note 26 supra.

47 On the other hand, many prospective secured creditors might not know about the progress payments clause or realize its significance. With such creditors, the contractor could obtain credit as easily as if there were no federal security interest.

48 I CCH INSTALLMENT CREDIT GUIDE $\$ 650$ (1966).

49 See, e.g., 6 G.F.R. $\$ \$ 307.1($ c), 307.2(f)(I) (1966). Compare 13 C.F.R. $\S 122.7$ (1966) with 12 C.F.R. § 122.17 (Supp. 1966).

50 See, e.g., United States v. Union Livestock Sales Co., 298 F.2d 755 (4th Cir. 1962); Bumb v. United States, 276 F.2d 729 (9th Cir. 1960).

51 Bumb v. United States, 276 F.2d 729 (9th Cir. 1960); cf. United States v. Brabham, 122 F. Supp. 570 (E.D.S.C. 1954). The opinions give no clue as to why the federal courts have treated the FHA and SBA differently from the Defense Department. With respect to the former agencies, both counsel and judges seem to have taken it for granted that they would comply. Bumb v. United States, 276 F.2d 729, 735-36 \& n.13 (9th Cir. 1960). The primary question the FHA cases dealt with was whether federal or state law should govern the federal government. While the circuits were far from consensus, several held that the other governmental agencies had to record according to state law. See United States v. Somerville, 324 F.2d 712 (3d Cir. 1963); United States v. Union Livestock Sales Co., 298 F.2d 755 (4th Cir. 1962); United States v. Kramel, 234 F.2d 577 (8th Cir. 1956).

52 See note 44 supra. 
vate and public secured parties to shoulder the expense indicates the relative importance of the interests involved. The Department of Defense's exemption from filing requirements is an anomaly that appears to have no reasonable support.

If the Defense Department were required to file its interest, defense needs probably would require a change in the usual penalty for failure to perfect an interest, that is, subordination of the security device. For example, if a contractor has completed ninety per cent of a missile system before becoming insolvent, national security requirements may dictate that, regardless of failure to file, the Department be allowed to take possession of the partially completed product so another contractor may rapidly finish construction. To accommodate this need, the penalty for the Defense Department's failure to file might be to give it the option to replace the removed property with money equal to the property's value without setting off its claims against the contractor. ${ }^{53}$ If the government exercised this option, the money paid into court would stand in the place of the collateral; whether the Department would then have the senior or the junior claim to the money would depend upon the resolution of the priorities question, an issue that will be discussed subsequently. ${ }^{54}$

Although there are several methods by which the Department of Defense might be required to file its interest, the easiest approach would be for the agency to amend the ASPR so that the contracting officer would file the title passing provisions of the contract according to state law. This could, however, leave private creditors without a remedy in the event the contract were not filed because administrative regulations often lack the force of law. ${ }^{55}$ Therefore, Congress might

53 The Department's need quickly to obtain the partially completed products may explain why the federal courts consistently exempted the agency from recording requirements. The judiciary may have feared that invalidating the Department's interest would hamper national security efforts because a secured creditor with an invalid security interest, such as the Department, usually only regains possession of the property by waiting until there is a judicial sale. On the other hand, the Seventh Circuit in In re Greenstreet, Inc., 209 F.2d 660 (1954), allowed the Department of Defense immediately to acquire army clothing needed for the Korean War without prejudice to the bankruptcy trustee's rights to sue the government for compensation. Thus, the courts probably could have accommodated the need for rapid contract performance and for filing of Department of Defense security interests within existing precedent.

54 See text following note 70 infra.

55 Perkins v. Lukens Steel Co., 310 U.S. 113 (1940); Hartford Accident \& Indemnity Co. v. United States, 127 F. Supp. 565 (Ct. CI. 1955). But cf. Paul v. United States, 371 U.S. 245 (1963). See generally Comment, Defense Contractor's Peril: The Written Agreement May Not Contain All the Terms, 37 So. CAL. L. Rev. 452 (1964).

Moreover, although the Federal Tort Claims Act, 28 U.S.C. § 2674 (1964), made the government liable for torts in the same manner and to the same extent as a private 
institute a more comprehensive solution by establishing a national filing system for government contracts that contain security interests. Such a system might resemble the arrangements presently in effect under the Ship Mortgage Act of $1920^{56}$ and the Civil Aeronautics Act, ${ }^{57}$ which require security interests in vessels and aircraft to be registered with federal authorities in order to be perfected. The result of not filing might again be that the government would be unable to set off the contractor's debts against its liability to pay for the reclaimed property, rather than ordinary subordination of the security device.

Another congressional approach could be a statutory requirement that all contractors post a bond, similar to that required under the Miller Act, ${ }^{58}$ for the protection of creditors and purchasers. Historically, however, Congress has been lenient in exempting contractors from this requirement, presumably in order to expedite defense procurement. ${ }^{59}$ Consequently, it seems unlikely that a bond remedy would be adopted.

If administrative or congressional action were not forthcoming, there remain two unexplored avenues that might enable a bankruptcy trustee or a secured creditor to persuade a court to subordinate an unfiled government interest. It is to be expected that the court would then allow the government to take possession of items essential to the na-

individual under like circumstances, neither agent nor principal are normally liable in tort merely because the agent violates a duty owed to his principal. Rather, the agent must violate a duty owed to a third party. Knight v. Atlantic Coast Line R.R., 73 F.2d 76 (5th Cir. 1934); Tippecanoe Loan \& Trust Co. v. Jester, 180 Ind. 357, 101 N.E. 915 (1913).

Further, an injured creditor would have to distinguish cases holding that the federal government is not responsible for the negligence of its agents. Federal Crop. Ins. Corp. v. Merrill, 332 U.S. 380 (1947) (mistaken approval by government agent of application for crop insurance where the crop was not insurable under regulations of the insurance corporation).

Finally, while the Tucker Act, 28 U.S.C. $\$ 1346$ (1964), allowed citizens to sue the government for contractual claims, a creditor could probably not sue as a third party beneficiary of the prime contract since the ASPR regulation requiring filing would presumably not be incorporated into the contract.

5641 Stat. 1000-08 (1920), 46 U.S.C. \$\$ 911-61 (1964).

57 Presently the Federal Aviation Act of 1958, 72 Stat. 772, 49 U.S.C. $§ 1403$ (1964).

5840 U.S.C. $\$ \S 271(a)$-(e) (1964). The statute requires those contractors awarded contracts over $\$ 2,000$ for the construction, alteration, or repair of any public building or public work to furnish a performance bond to protect the federal government and a payment bond to protect all persons supplying labor and materials.

58 The act was amended in 1941, 55 Stat. 147, 40 U.S.C. $\$ 270$ (e) (1964), to allow the secretaries of the various services to waive the posting of a bond in supply contracts.

Two other considerations detract from the bond possibility. The contractor's cost of procuring a bond is reflected in his bid for the contract. Further, since the contractor does not obtain a bond until he has been awarded the contract, performance may then be delayed while he attempts to raise the bond. 
tional defense if it agreed to pay for the property without setoff once the price was determined..$^{60}$

First, the bankruptcy trustee might utilize the concepts of the amorphous and rapidly developing federal common law. ${ }^{61}$ The Supreme Court has held that contracts to which the federal government is a party, such as those containing progress payments clauses, shall be governed by federal common law. ${ }^{62}$ The theory supporting this doctrine is that there are situations in which an overriding federal interest requires a nationally uniform rule that supersedes conflicting state law. The federal courts are free in these situations to fashion rules as they believe best. When there is no need for such uniformity, but for some reason the courts have decided that federal common law should still apply, ${ }^{63}$ the judiciary may adopt state law as the controlling federal law.64 The bankruptcy trustee might therefore argue, by analogy to the Farmers Home Administration and the Small Business Administration, that the progress payments clause does not require national uniformity. ${ }^{65}$ If these agencies have the manpower to comply with state variations in filing, then the Defense Department should have that ability. Since there is no need for uniformity, federal common law could adopt state

60 For an example of a court's allowing the agency to obtain possession in this manner, see In re Greenstreet, Inc., 209 F.2d 660 (7th Cir. 1954).

61 United States v. Yazell, 382 U.S. 341, 343 (1966), and Wallis v. Pan American Petroleum Corp., 34 U.S.L. WEEK 4373 (U.S. April 26, 1966), are illustrative of both the ambiguity and the constant flux that presently characterize the federal common law. See also Note, The Competence of Federal Courts to Formulate Rules of Decision, 77 HaRv. L. REv. 1084 (1964).

62 See Clearfield Trust Co. v. United States, 318 U.S. 363 (1943) (state law on negotiable instruments inapplicable in determining the liability of the United States on a check issued by the Treasurer of the United States). The case is commonly cited as originating the proposition that when the United States is exercising a constitutional function or power, "in absence of an applicable Act of Congress it is for the federal courts to fashion the governing rule of law according to their own standards. . . . In our choice of the applicable federal rule we have occasionally selected state law." Id. at 367 . See generally Friendly, In Praise of Erie-And the New Federal Common Law, 39 N.Y.U.L. REv. 383, 410 (1964).

63 If an overriding national interest requires the application of federal common law, the use of state law as the content of federal common law seems inconsistent. But the courts have regularly used this rhetoric. See, e.g., Clearfield Trust Co. v. United States, 318 U.S. 363,367 (1943).

64 E.g., DeSylva v. Ballantine, 351 U.S. 570 (1956) (whether an illegitimate was a "child" entitled to renewal interests under the Copyright Act decided according to federal common law incorporation of state law).

65 The difference between FHA or SBA loans and progress payment advances seems insignificant. Supporting this view, Consolidated-Hammer Dry Plate \& Film Co. v. Commissioner, 317 F.2d 829, 832 (7th Cir. 1963), held that for income tax purposes the progress payments clause "is characteristic of the security frequently taken by a creditor, who makes advances. ... [T] arrangement." But cf. Boeing Co. v. United States, 338 F.2d 342 (Ct. Cl. 1964). 
filing statutes as controlling. The Fourth, Eighth, and Ninth Circuits ${ }^{86}$ have recently provided limited support for the trustee by stating that, as a matter of federal common law, the FHA and SBA security devices must conform to state filing statutes. On the other hand, the government could attempt to distinguish the FHA and SBA cases on the theory that the Defense Department's advances were similar to a purchase money security interest and, enlarging the Uniform Commercial Code's preferential treatment of such interests, should not have to be filed in order to prevail over competing interests. ${ }^{67}$

Approaching the problem more directly, a secured party could argue that the Armstrong decision applies to the government's acquisition of title under the progress payments clause. ${ }^{68}$ This position is supported by interpreting the Court's holding to require that whenever the government's interest is not perfected by filing, so as to notify third parties of its claim, its reclamation of property is a taking in violation of the fifth amendment if private security interests are thereby subordinated to the agency's claim. Also supporting such an approach is Mr. Justice Black's remark, in Armstrong, that the government should not force "some people alone to bear the burdens [that is, the costs of shipbuilding] which, in all fairness and justice, should be borne by the public as a whole." 69 On the other hand, the Court's concern with the holder of title at the time that the liens came into existence suggests that the government might not, by this theory, be forced to compensate the creditors if the government has title to the property when the private liens are created. ${ }^{70}$

II

The Uniform Commercial Code separates contests between competing security interests into two parts. ${ }^{71}$ Since perfected interests are prior

66 United States v. Union Livestock Sales Co., 298 F.2d 755, 759 (4th Cir. 1962) (dicta); Bumb v. United States, 276 F.2d 729 (9th Cir. 1960) (although federal law controls the filing of the SBA's chattel mortgage, the agency must meet state requirements); United States v. Kramel, 234 F.2d 577, 580 (8th Cir. 1956) (dicta) (in a suit for tortious conversion of property, state recording requirements are an applicable part of the ruling federal law). 67 See the discussion of priorities following note 70 infra.

68 The trustee would emphasize that a mortgagee's lien is property that cannot be taken without just compensation, either by the right of eminent domain, Thibodo v. United States, 187 F.2d 249 (9th Cir. 1959), or by legislation weakening the security device, Louisville Joint Stock Land Bank v. Radford, 295 U.S. 555 (1935). See also 59 MICH. L. REv. 957 (1961); 109 U. PA. L. REv. 275 (1960).

69364 U.S. 49 (1959).

70 The only two relevant cases decided since Armstrong interpreted the decision in this way. Shepard Engineering Co. v. United States, 287 F.2d 737 (8th Cir. 1961); United States v. Ameco Electronic Corp., 224 F. Supp. 783 (E.D.N.Y. 1963).

71 Compate UNIFORM COMMERCIAL CODE § 9-312 with id. \$§ 9-302-03. 
to virtually all unperfected ones, ${ }^{72}$ the first inquiry is whether the interest has been perfected-for example, by filing. Secondly, the question of priority among perfected interests is decided, giving consideration to such factors as the purpose of the loan..$^{73}$ Although the courts have, as indicated above, lumped both of these issues together when considering the progress payments clause, Armstrong and the other relevant cases may be interpreted as immunizing the Defense Department from the perfection requirement ${ }^{74}$ and the ensuing loss of priority that would result from failure to perfect. Such judicial amalgamation of the perfection and priority issues, however, may lead to priority determinations based only on when the security interest is created, thus obscuring the possibility that other perfected interests might be given priority over the Defense Department's claim when factors such as the purpose of the loan are considered. This section will consider how the courts might rank the Department's interest if they believed that these added factors were useful and, by analogy with the Code, addressed themselves to the priorities question as an issue separate from perfection. The discussion will first consider how a perfected government interest would be treated under the $\operatorname{Code}^{75}$ and then propose alterations in the Code's dispositions a court might make if it were to use the statute

72 See UNIForm CoMmercial CODE $\$ \S 9-301(1)-(2)$.

73 See, e.g., UNIForm CoMmercial CODE \$§ 9-312(3)-(4).

74 Literal application of the Code's rules might require the Department's interest to be treated as unperfected because the only way for that agency permanently to perfect its interest under the Code would be by filing a financing statement. See UNIFOrM CoMmerCIAL CODE § 9-302(1). This result appears unlikely, however, because in deciding whether a security interest is "perfected," a legislature or a court is really determining whether that interest should be entitled to certain priority results. In considering both private parties' claims, see note 28 supra, and bankruptcy trustee arguments, see note 15 supra, the federal courts have clearly decided that the Defense Department's title is entitled to those priority results associated with a "perfected" interest. See cases cited note 5 supra. In other words, the Department's claim appears to be perfected by operation of law at the time of contract signing. If a court were to articulate a reason for so treating the agency's claim, it might rely on Congress' desire to conserve public funds and the analogy with the purchase money security interest. See text following note 87 infra.

75 Even though the Uniform Commercial Code establishes an elaborate system of priorities (see UnIForm Commercial Code $\S 9$, pt. 3, especially § 9-312) that attempts to settle possible conflicts between interests in negotiable instruments, farm equipment, assigned contract rights, ordinary goods, and numerous other types of property, the following discussion and all statements concerning the Code's priorities will assume that the contractor's collateral is only goods, that is, tangible property such as materials, inventory, and plans. Further, none of these goods will be treated as covered by documents of title, negotiable or nonnegotiable instruments, or intangible claims other than competing security interests. See UNIFORM COMmercial CODE $\S \S 9-304,308-09$. Furthermore, the priorities of competing security interests covering fixtures, accessions, and conmingled goods are not considered in the discussion. See UNIFORM COMMERcial CODE §§ 9-813-15. 
as a guide in settling priority contests involving Defense Department contracts.

Rather than discuss the multitude of interests ${ }^{76}$ that could compete for the debtor's property, the ensuing discussion will use two hypothetical creditors to illustrate generally the kinds of challenges the government might face under the Code. First, a private party could assist in financing the contract itself. Normally this would not occur since a contractor receiving the seventy per cent reimbursement provided by the government would probably not need additional financing; also such a situation would tend to alert lenders to the government's prior claim, making them wary of the collateral involved. On the other hand, the contractor might receive only twenty or thirty per cent reimbursement, or the lender might not realize the contractor had government assistance. Second, a private party may have advanced money to the contractor before there ever was a government contract, such loan being secured by an agreement covering all after acquired property. ${ }^{77}$ This probably would occur only when the contractor received materials or inventory financing since secured parties tend to separate longterm financing covering real property, machinery, and other durable goods (not typically covered by the progress payments clause) from short-term financing encompassing items such as accounts receivable and inventories. ${ }^{78}$ The significant difference between these two types of secured creditors is that the second party would not have given new consideration for the additional collateral-the after acquired property. This additional collateral probably augmented previous collateral, the latter having been the only existing property that the lender originally subjected to a security interest in order to secure the loan. The first secured creditor, however, claimed collateral that, existing at the

76 Perfected security interests in the same property may have been created either before or after the Department advanced progress payments. If before, the competing party's security arrangement would necessarily contain a clause covering after acquired property. See UNIForm Commercial. Code § 9-204(3). Further, a private party might have a purchase money security interest, UNIFORM CoMmERCIAL CODE \$§ 9-312(3)-(4), or have made further advances to the contractor after the security arrangement was completed (so called future advances). See 2 Gilmore, Security INTERests IN Personal Property §§ 35.6-.7 (1965). Besides having security interests, the competing parties could be lien creditors, bulk transferees, buyers not in the ordinary course of business, see UNIFORM COMMERcial CODE $\S 9-301(1)$, buyers in the ordinary course of business, see UnIForm Commercial Code § 9-307(1), or materialmen with statutory liens, see UNIForm CoMMERcial CodE § 9-310.

77 In this case, the private party's original collateral would probably be unrelated to the government contract. A contest between the Defense Department and the private party would thus arise only if the after acquired property clause were sufficiently broad to include the property to which the Defense Department held title.

78 See I Gilmore, Security Interests in Personal Property § 8.1 (1965); cf. I Coogan, Hogan \& Vagts, Segured Transactions Under the Uniform Commercial Code § 7.11(3) (1963). 
time the loan was made, necessarily constituted new consideration for that loan.

If a court were to abide strictly by all of the Code's provisions, ${ }^{79}$ the Department of Defense's interest could be treated as either a perfected security interest ${ }^{80}$ or a perfected purchase money security interest. If an ordinary perfected interest, the Department's claim would be subordinate to perfected purchase money security interests and all security interests perfected before the Department perfected its interests. Moreover, if the agency were to file its interest, as previously urged, its claim would still be subordinate to earlier filed interests if both competing interests were perfected by filing. ${ }^{8 I}$ Thus, the party with an after acquired property clause would prevail over the agency, and whether a private financier of the government contract would prevail would depend on which party first perfected or filed.

Since simple perfection would not give the government priority over many competing interests, the Department could be expected to argue that the progress payments fell within the statute's definition of a perfected purchase money security interest, thus making its interest superior to both categories of competing creditors unless one of them also had a perfected purchase money security interest, in which case the two would share the collateral according to the extent that their monies were used to purchase the property. ${ }^{82}$ But it would be very difficult for the progress payments to qualify as a purchase money security interest, that is, an interest securing money advanced for the purpose of and actually used to enable the contractor to acquire rights in the collateral. ${ }^{83}$ As the ASPR clauses are presently drafted, the requisite purpose would be almost impossible to prove; further, tracing the funds from

79 Several possible competing parties have fairly well defined priorities under the Code. If a materialman with a statutory lien has possession of the collateral, his claim may be superior to perfected security interests. See Uniform Commercial Code § 9-310. Although buyers in the ordinary course of business take free of all security interests, see UNIFORA CoMmercial CODE \& 9-307(1), the priority problem remains since the secured parties then compete for the right to the proceeds from the sale. UNIForm Commercial Code $\$$ 9-306. A perfected purchase money security interest is usually superior to all competing interests except the preceding two claims. See UNIForm Commercial Code §§ 9-312(3)-(4). As between two parties with perfected security interests, priority depends on who filed first if both were perfected by filing, or who first perfected if one interest was perfected by a method besides filing (for example, by initially taking possession of the collateral). See UNIFORM COMMERCIAL CODE \$\$ 9-312(5)-(6).

80 Except during the period of time it retained possession of the collateral, the Department would have to file a financing statement to perfect its interest. See UNIFORM CoMMERCIAL CODE § 9-302(l).

81 Unifora CoMMrercial CODE $\$$ 9-312.

82 Compate Uniform Commercial Code $\$$ 9-107 with Uniforar Comimercial Code $\S \S 9-312(3)-(4)$.

83 Uniform Commercial CODE \& 9-107(b). 
the agency to the purchase of materials, tools, and the like would also pose a serious obstacle. ${ }^{84}$ Thus, even if the government were to file the necessary financing statement, the progress payments probably would not qualify as a perfected purchase money security interest.

Within the Code's framework, therefore, the Department of Defense's security interest might well be subordinated to one or both hypothetical private parties even if the agency filed. But a court merely borrowing from the Code undoubtedly would be free to modify the statute's provisions where it seemed appropriate. If a court were to use this freedom, four policy considerations suggest themselves as relevant to the final decision: (1) the private party's knowledge of the government's interest, (2) the giving of new consideration for the right to claim the contested collateral, (3) the ratable sharing of collateral to which parties have equal claims, and (4) the Department's incentive to file.

First, a court might question why the Code's section 9-312 priorities ignore a secured party's knowledge of the competing security interest since the purpose of a filing system is presumably to notify prospective creditors and purchasers of the existence of outstanding claims. If the private party knew of the Department's claim when he gave value to the contractor, there is no apparent reason why the government's claim should not prevail..$^{85}$ In addition, if the private individual reasonably should have known of the progress payments even though he lacked actual knowledge, such knowledge could be imputed to the creditor in order to promote diligent investigations.

Second, as noted earlier, the significant distinction between the two

84 See 2 Gilmore, Security Interests in Personal Property \& 29.2 (1965). Revision of the progress payments clause, however, could easily incorporate the necessary purpose, and careful accounting by the contractor might demonstrate that the progress payments were actually used to buy the collateral. Once the contractor made the initial outlays, entitling him to reimbursement, the Defense Department's advances would probably cover the cost of the vast majority of collateral subsequently acquired, especially since the progress payments are based on "total costs," thus including the expenses of overhead and labor as well as the cost of materials.

85 Cf. UnIForm Commercial Code § 9-301(1). Compate 2 Gllmore, SeCuRtTy INTEREsts IN Personal Property \& 34.2 (1965) with Braucher, Book Review, 33 U. CHI. L. Rev. 890, 897 (1966). On the other hand, if the private party, although aware of the government's interest, reasonably believed his claim would be superior to the Department's, then he should be treated as a party without knowledge. This possibility could occur if the private party thought the progress payments were unsecured advances.

If the Department knew of the private party's unsecured interest before making the progress payments, its claim might similarly be subordinated. It seems unlikely, however, that the government would provide progress payments if there were any significant private security interests covering the same collateral unless it could obtain a subordination agreement from the private party. 
hypothetical private parties is that one did not give new consideration for the additional collateral-the after acquired property. Had the government contract not been consummated, the secured party would not have had a claim to the contested property since presumably that property would not have been purchased. In this situation, there seems to be no injustice in subordinating the private party's interest to the Department of Defense's claim, especially if the government has paid seventy per cent of the cost of the added collateral. ${ }^{86}$

Thus, a court might prefer the Department's interest to those of competing secured parties if the latter had knowledge of the government's claim or if the private creditor did not advance new value in consideration for the right to claim the contested property as collateral.

But what of an unknowing private party that did give new value, for example, a creditor who regularly financed the contractor's inventory acquisitions? Both competitors might attempt to justify priority on the basis of the policy underlying the Code's special treatment accorded perfected purchase money security interests. ${ }^{87}$ Although the policy behind this preferred priority is not clear, ${ }^{88}$ it may rest on the

86 Not all after acquired property clauses would be subordinate to the government's claim; for example, if a party advanced new value simultaneously with the contractor's acquisition of collateral covered by an after acquired property clause-the so-called case of "future advances"- that party's security interest might be superior to the Department's. See 2 Gilmore, Security Interests in Personal Property \$§ 35.6-.7 (1965).

The unlikely case in which the private party did not provide additional consideration, but the government did know of the private party's security interest, presents precisely the kind of situation in which the Code carves out a special priority for purchase money security interests. Even if all of the Code's requirements were met, however, it appears preferable to have the government's claim subordinated to that of the private party because there is no apparent need to facilitate government contracting as there is a possible need to promote the national movement of goods from producers to users. See note 88 infra.

87 Ignoring the Armstrong rule that the first party to acquire its interest prevails, the following discussion applies equally to private parties who advanced value before and after the government acquired its interest.

88 See, e.g., 2 Coogan, Hogan \& Vagts, Secured Transactions Under the Uniform Commercial CODE $\$ 19.06$ (1964), where Professor Hogan suggests that the preferred priority of the perfected purchase money security interest may be the result of a national concern for facilitating the movement of goods from producers to users. Thus, without the purchase money security interest priority, lenders would be less inclined to extend credit for specific purchases when there was a prior perfected security interest; consequently, some buyers would be unable to acquire the goods they desired. However sound this policy may be in ordinary business dealings, it does not significantly support the Defense Department's claim for priority; government procurement will take place irrespective of the progress payments' priority classification.

In order for a party to have a perfected purchase money security interest in inventory under the Code, he must notify prior secured creditors of his claim before the debtor obtains possession of the property. Such actual notification is not required for other purchase 
belief that a competing party's collateral is not substantially impaired when the purchase money secured party takes his interest, ${ }^{89}$ either because the competing party's collateral is rarely used to finance the particular purchase, ${ }^{90}$ or because the secured party augments the debtor's total assets at the same time he acquires the priority. ${ }^{91}$ While either or both of these assumptions may generally be true, they do not necessarily apply to Defense Department progress payments. In particular, the contractor might use a loan by the competing party that was not especially earmarked for contract purchases to supply the thirty per cent of the purchase price that was not advanced by the Department. ${ }^{92}$ In this instance, if the Department's loan were treated as a purchase money security interest, the competing party's claim would be junior to that of the government.

When both the government's progress payments and a portion of the private party's collateral are used to finance the contractor's purchases, there is no apparent reason why either claim should have priority over the other, unless one adopts a first in time rule, a possibility that the purchase money security interest priority explicitly rejects. Therefore, a court might then consider the third policy, namely, that parties with equal claims to collateral may ratably share the property.

Such a proportional allocation of the collateral could be accomplished in either of two ways. The property might be divided accord-

money security interests. See UnIForm CoMmercial CODE \$§ 9-312(3)-(4). Although the Code's comments explain this difference on the basis of a greater possibility of fraud with inventory financing, it would appear that inventories are indistinguishable from other purchases, except to the extent that inventories are more expensive (if that is true). Thus, it would seem that both types of purchase should be treated the same, depending upon the extent to which actual notification is deemed desirable.

89 Professor Gilmore appears to make this assumption in his discussion of purchase money security interests. See 2 Gilmore, Security INTERests in Personal Property $§ 29.2$ (1965).

90 If the debtor were to dispose of property subject to the competing party's security interest, using the proceeds to finance the purchase, the secured party might also have a security interest in the newly purchased property. See UNIFORM COMMERcial CoDE § 9-306. On the other hand, the later security interest of the private party would not be a purchase money security interest and would thus be subordinate to a perfected purchase money security interest in the same property.

91 For example, a private party with a security arrangement covering all of the contractor's property would have the collateral to which he had a superior claim reduced by a purchase money security arrangement that, while advancing $\$ 50$ to the contractor, included a $\$ 100$ purchase as collateral for the government's loan.

92 On the other hand, if the private loan were a purchase money security interest and the government's advances were also treated as a purchase money security interest, the two parties would share the collateral under the Code's provisions in proportion to the extent to which the monies were actually used to purchase the collateral. Compare UNIFORM COMMERCLAL CODE § 9-107 with id. §§ 9-312 (3)-(4). 
ing to the value each creditor contributed to the debtor. Thus, if $A$ contributed 3 and $B$ contributed $5, A$ would receive $3 / 8$ and $B 5 / 8$ of the value of the property. ${ }^{93}$ On the other hand, $A$ may have been more cautious than $B$ in his lending and may have demanded collateral worth 10 for his loan of $3 ; B$ may have only had property worth 8 to secure his loan of 5 . In order to reflect such variations in the parties' willingness to accept risk, $A$ and $B$ might share the property in proportion to the value of the collateral securing the loans. Thus, $A$ would receive $10 / 18$ and $B 8 / 18$ of the property; ${ }^{94}$ once either party recovered the full amount of his loan, however, the other would receive the remainder of the property up to the amount of his advance. ${ }^{95}$

Although it might appear that either method of ratably dividing the property would be more equitable than granting one party a superior claim, a court might prefer the simplicity of the latter approach over the possible complexities of dividing the collateral, especially if the court could not choose between the two above methods of allocation. In that event, it could consider the fourth factor, that is, the Department's incentive to file a financing statement in the future. Were its interest superior to the private party's claim, the Department would have no reason to file future progress payments contracts. On the other hand, by subordinating the government's claim the court would effectively encourage such filing, ${ }^{96}$ thereby promoting constructive notification of other parties of the Defense Department's claim. ${ }^{97}$ Once private parties had such knowledge, the government's interest would then prevail, as explained earlier.

If it were to apply these four policy considerations to contests in-

93 See 2 Gilmore, Security Interests in Personal Property § 31.5 (1965).

94 In § 9-315, the Uniform Commercial Code establishes a similar method of dividing the collateral: competing interests share in proportion to the cost of their respective collaterals. Professor Gilmore criticizes this approach as inequitable, suggesting that the parties should share according to the value each contributed to the debtor. See 2 GiLmore, Security Interests in Personal. Property § 31.5 (1965).

95 While it would seem that these two methods of ratably dividing the collateral might be combined to reflect both the amount of money loaned and the degree of risk assumed, a suitable compromise is extremely difficult. A nonsense answer results if the ratios between the values contributed and the values of the collaterals are multiplied, divided, added, or subtracted.

96 See also Uniform Commercial Code § 9-312 comment 3, example 1, where the Code authors suggest that one reason that fling gives a secured party a claim superior to subsequent filings, irrespective of the order of advances or knowledge, is "the necessity of protecting the filing system."

97 On the other hand, one should not be surprised if courts were to rule in favor of the government. Despite the Department's failure to file, it seems reasonable to assume that professional financiers are aware of the progress payments security interest or would discover its existence before making a substantial loan to the contractor. 
volving progress payments, a court might depart from the Uniform Commercial Code's priority treatment of unperfected security interests, lien creditors, buyers not in the ordinary course of business, and bulk transferees. ${ }^{98}$ If these creditors failed to provide new consideration for their claim to the collateral, the Department's interest would be superior. On the other hand, if they lacked knowledge, they would either ratably share the collateral with the Department, or they would prevail over the government in order to encourage future filing.

The application of the foregoing policy considerations to statutory mechanics liens deserves special mention since many of the cases have concerned these claims. Although the Code provides that their interests shall prevail only so long as they have possession of the collateral,99 this requirement might be ignored because the reason for requiring possession has never been clearly articulated. Furthermore, despite the Code's contrary implication, the knowledge of the government's claim by a materialman might subordinate his claim to that of the Department. Moreover, the rationale for materialmen's priority appears to be based on the same policy that underlies the purchase money security interest priority ${ }^{100}$ which, as discussed earlier, leads to the conclusion that competing parties without knowledge should share the collateral.

Although the preceding discussion refers generally to the Department of Defense's secured claim, it is useful to separate the claim's two principal components-the demand for repayment of the progress payments, and the claim for payment of all costs in excess of the contract price that are required for another contractor to complete performance. The latter sum of money represents, essentially, the government's damages caused by the contractor's breach. In contrast to the claim for repayment of the progress payments, the Department has not advanced to the contractor, in connection with these damages, any value that augmented his total assets. There is no apparent reason why, lacking filing, the government's claim should receive priority here. If the Department filed, thus bringing the damage claim within the Code's expansive definition of a security interest, this arrangement would remain unusual since even when the defaulting party is solvent, damage awards do not always place the other party to the con-

98 See Uniform Commercial. Code § 9-301(1).

99 See UNIFORM COMMERCIAL CODE § 9-310.

100 That is, since materialmen presumably enhance the value of the property to the extent of their claim, the original secured creditor has the same amount of collateral after the materialman is paid as he had before the materialman appeared on the scene. 
tract in the same position he would have occupied if the contract had been fully performed. ${ }^{101}$

When the foregoing discussion of priorities is applied to the Armstrong case, the Court's opinion is significant more for its approach to the problem and the questions it raised than for the answers it supplied. Mr. Justice Black's approach, reliance on the concept of "title,"102 contrasts rather sharply with the Uniform Commercial Code's careful separation of the perfection and priorities issues and its emphasis on clear, "objective" rules that are not as manipulative as "title." Probably, Mr. Justice Black was influenced by the fact that the "title" concept easily accomplished the desired result-subordination of the government's claim-and that all prior cases in the area have relied on discussions of locations of title to reach their result. ${ }^{103}$ Read narrowly, the Court's holding was that a defense contract title passing provision, without more, was subordinate to a prior statutory mechanics lien. Beyond this immediate result, however, the implications of the decision for the kinds of problems discussed here are particularly cloudy. Probably the mechanics lien is the equivalent of a perfected security interest, and the Defense Department's title will be treated as perfected by the operation of law. Thus, Mr. Justice Black's opinion may have decided that a perfected Department of Defense interest will not prevail over a prior perfected private interest. But what about contests between a perfected government interest and prior unperfected private interest? Moreover, if the Department's interest was not considered perfected after all, would the

101 See generally Fuller \& Perdue, The Reliance Interest in Contract Damages, 46 YALE L.J. 52 (1936).

102364 U.S. 40, 44, 46 (1959).

103 See cases cited note 5 supra. Although the analysis in the Armstrong opinion failed to realize that a security interest was involved, such an approach is more understandable when placed in historical perspective. The "title" analysis in Ansonia was completely in keeping with the commercial law of that time. The next case to arise, In re Read-York, Inc., 152 F.2d 313 (7th Cir. 1945), also preceded widespread use of modern secured transactions analysis; perhaps the Seventh Circuit in Read-York awarded the property to the government, even though the agency had not filed, because of the urgent need for defense materials for World War II. The next case, In re Greenstreet, 209 F.2d 660 (7th Cir. 1954), was also decided by the Seventh Circuit and naturally relied heavily on ReadYork. One year later, when the Third Circuit decided In re American Boiler Works, Inc., 220 F.2d 319 (3d Cir. 1955), it apparently relied on Ansonia and the two preceding Seventh Circuit cases. Thus, by the time the Armstrong Court grappled with the Defense Department's claim, there was a substantial heritage of "title" analysis that did not use the more recent terms "perfection" and "priority." Further, neither the brief of the plaintiffs nor that of the government demonstrated an understanding that the contest with the materialman was basically a secured transactions problem. 
government then be able to subordinate the prior private interest by perfection, perhaps through filing? Further, the Court's holding necessarily fails to determine the priorities of private interests subsequent to defense contract signing since the plaintiffs in the case were not such parties. Since the areas the Court did not consider and the questions it did not answer will probably be left to the lower courts, it is hoped that these courts will consider the Uniform Commercial Code's provisions, borrowing from that statute when appropriate. The only two reported cases since Armstrong, however, indicate that such may not be the case; ${ }^{104}$ the simplicity of the first in time rule, it seems, still has a persuasive appeal.

\section{CONCLUSION}

It remains disturbingly unclear why the Supreme Court or the lower courts have not discussed the possibility of requiring the Defense Department to file its security interests, since local secured parties and those dealing with subcontractors may not realize that the agency has a prior enforceable claim. Unlike their treatment of other agencies of the government and private secured parties, the courts have completely exempted the Department from filing requirements, justifying this by applications of federal common law and by focusing on the location of "title." In order to provide notice to prospective creditors, congressional statutes or altered judicial doctrines could force the Department either to file its interest or to replace reclaimed collateral with an equivalent monetary payment. Regardless of whether the agency files, however, the priorities issue is always present. In contrast to the courts' single factor approach, a first in time rule, the Uniform Commercial Code more rationally determines priority questions on the basis of several relevant considerations. Courts might profitably borrow from the Code in their treatment of the Defense Department and, while so borrowing, alter the statute's classification so as to reflect four policy

104 In both Shepard Engineering Co. v. United States, 287 F.2d 737 (8th Cir. 1961), and United States v. Ameco Electronic Corp., 224 F. Supp. 783 (E.D.N.Y. 1963), the courts held for the government largely because the Defense Department had "title" to the property, thus making it impossible for private liens to attach. The concepts of perfection and priority, and the various issues surrounding each, seemed quite distant. These two cases do not indicate, however, that Armstrong has had a profound influence on the lower courts; in the Ameco Electronic case, the court did not even cite Armstrong. Rather, it appears that the decisions prior to Armstrong continue to mold subsequent lower court decisions as effectively as they influenced the Armstrong opinion. 
considerations: the knowledge of the competing parties, the giving of new consideration, the possibilities of ratable sharing of the collateral, and the Department of Defense's incentive to file future security interests. 